\title{
Adoption of Corporate Social Responsibility: Board Competencies and Roles
}

\author{
Mohammed Naif Z Alshareef ${ }^{1} \&$ Kamaljeet Sandhu ${ }^{1}$ \\ ${ }^{1}$ UNE Business School, University of New England, Armidale, Australia \\ Correspondence: Mohammed Naif Z Alshareef, University of New England, Armidale, Australia. E-mail: \\ malshar4@myune.edu.au
}

Received: March 27, 2015

Accepted: May 16, $2015 \quad$ Online Published: May 25, 2015

doi:10.5539/ijbm.v10n6p75

URL: http://dx.doi.org/10.5539/ijbm.v10n6p75

\begin{abstract}
This study aims to discover non-executive directors' competencies that important to improve their roles towards the adoption of Corporate Social Responsibility (CSR). To begin with, the review of the existing body of literature on the topic of Corporate Governance (CG) codes and the survey of numerous postulations offered is conducted. A qualitative interpretive approach is adopted, based on in-depth interviews conducted with board and management levels of the two companies operate in Saudi Arabia. The key outcomes of the study suggest that (i) NEDs' independence represents a typical practice in CG and; (ii) NEDs' competencies and roles represent a governance issue which needs to be addressed via CG code to protect the stakeholder groups. The findings imply a shift in the recent focus on developing and reforming CG Codes towards CSR orientation and the growing role of NEDs in stakeholder's protection. The key contribution of the study can be found in the enhancement of the current level of understanding of non-executive directors' competencies and role and the improvement of CG codes to address the issue of stakeholder engagement. The multiple-theoretical framework including aspects of resources dependence, stakeholder and resource-based view of the firm theories allows for the interpretation of the link between NEDs competencies and roles in the CSR context. Board members and managers can find this study useful in improving the election criteria of NEDs' appointing mechanisms. Additional implications relate to policy makers as the need for increasing the regulatory capacity and legal systems in the area of CG reform is highlighted. Stakeholder's pressures and forced and normative variety in particular have the potential to enhance the level of CSR adoption.
\end{abstract}

Keywords: non-executive directors, competencies, board roles, corporate social responsibility and corporate governance

\section{Introduction}

Nowadays, corporate social responsibility (CSR) represents one of the most prominent issues for contemporary organisations. In line with the growing importance of this issue, the involvement of corporate board of directors in the assessment and shaping of corporate policies and practices in the area of social and environmental aspects can be observed. The structures as well as behaviour of corporate board have come under scrutiny as the CSR performance of companies is under the spotlight. Independent and proactive forms of management are required from corporate directors by shareholder activists and other stakeholder groups to reflect a wider range of constituents.

The definition of CSR reflects the companies' wider responsibility towards stakeholders and society in general. The economic success is no longer the only criteria on which corporations are being judged (Ayuso \& Argandoña, 2009; Carroll, 2000; Hazlett, McAdam, Sohal, Shahin, \& Zairi, 2007; Jamali, 2008; Willard, 2012) pointed out, organisations are "no longer expected to be mere contributors to the global economy, but rather to reconcile and skill-fully balance multiple bottom lines and manage the interests of multiple stakeholders". Despite the growing interest in CSR, the actual performance of CSR practices is found to be relatively limited on a global basis. One of the explanations for this gap can be found in the works of Ayuso and Argandoña (2009); C. Ingley and Van Der Walt (2005); C. B. Ingley (2008) who suggested that it is the lack of ability and competency amongst boards of directors which impedes the achievements in the CSR domain. In line with the underlying CSR movement, major decision makers and boards of directors in particular are accountable to a wider a range of stakeholders. As a result, the exploration of non-executive directors' competency and role in CSR is of a critical importance. 


\subsection{The need of non-executives director (NED)}

The role of NEDs is found to represent the key for ensuring corporate accountability and hence, recent studies have focused on the methods of increasing board effectiveness and enhancing CG (Ayuso \& Argandoña, 2009; C. Ingley \& Van Der Walt, 2005; McNulty, Florackis, \& Ormrod, 2013; Nicholson \& Kiel, 2004). Following the recent scandals around the globe, the response from the policy makers to managers' misappropriation can be found in addressing the conflicts of interest in large corporations as well as demanding a greater independence of board from subjects inside and outside of the company that exert substantial power (Aguilera, Williams, Conley, \& Rupp, 2006).

Consequently, reinforcement of the codes and rules for non-executive directors has occurred. In the context of the US, the Sarbanes-Oxley Act (2002) and the new New York Stock Exchange listing rules (2003) assert that publicly traded companies should have boards composing of a majority of independent directors and the same goes for the audit committees which should be made up of independent directors entirely (Aguilera et al., 2006; Pass, 2004; Sarbanes, 2002; Zattoni \& Cuomo, 2010; Alshareef \& Sandhu, 2015). In the UK context, changes in the board composition recommendations can be traced back to the review undertaken by Sir Higgs in 2003. The introduction of the Combined Code resulted in presence of independent non-executives for a minimum of half of the seats on the board, separation of chairperson and CEO's positions, ensuring that the majority of directors in the nomination committee are indecent and developing independence of audit and the remuneration committees. Similar actions can be found in other countries and their recommendations on board composition and independence(Aguilera et al., 2006; Pass, 2004).

Based on the codes and rules introduced, the empirical body of research recognises some effectiveness of non-executive directors in safeguarding corporate accountability. Three broad conclusions can be observed from this body of research. First, non-executive (mostly independent) directors are essential for the provision of monitoring of a company's financial reporting practices (Aguilera et al., 2006; Pass, 2004; Zattoni \& Cuomo, 2010). Secondly, the protection of shareholders' interests in key board outcomes including CEO substitution, reaction to potential takeovers, implementation of anti-takeover defences and top management's compensation has been enhanced by non-executive directors (Hermalin \& Weisbach, 2001; Huse, 2005). Thirdly, agency theory underpins most of the CG codes and as such the emphasis is put on protecting shareholders' instead of stakeholders' interests.

The importance of NEDs can be examined from a number of perspectives. From a legal and commercial viewpoint, NEDs represent an essential guarantee of integrity and accountability of an organisation (Pass, 2004). The independent judgment provided by non-executives safeguards the interests of a company's shareholders. Additional benefit can be found in the contribution of non-executive directors in terms of providing valuable external business expertise for the company. Based on their diverse backgrounds, non-executive directors can recognise potential risks and opportunities which could have been overlooked by the company's executive engaged in daily operations of an organisation (Zattoni \& Cuomo, 2010). Particular benefits can be achieved in the case when executive chairman or chief executive of the company is highly entrepreneurial or over-influenced by moderating excesses. The connections of non-executives can result in business opportunities which would not be available otherwise. Finally from a structural point of view, non-executives are often required to guide companies through a period of corporate transitions (e.g. changes in ownership, re-positioning of the business) (Ayuso \& Argandoña, 2009; Pass, 2004; Zattoni \& Cuomo, 2010).

Despite the numerous advantages of non-executive directors, a number of potential limitations of their effectiveness need to be acknowledged. On one hand, NEDs are employed on a part-time basis and their commitments may go beyond the company. Consequently, the needs of the company and challenges faced by the company may remain neglected due to limited time dedicated from NEDs (Pass, 2004). The National Association of Pension Funds has been forced to limit the number of non-executive directorship to no more than five following the practical difficulties arising from multiple directorships. On the other hand, non-executive directors may not fully understand the technical and complex issues faced by the business. Lack of information, either being unavailable or withheld, may impede an informed decision making process (Zattoni \& Cuomo, 2010).

\subsection{NEDs' Roles and Competences}

Multiple CG guidelines and codes of best practices, on both national and international levels (e.g. OECD Principles of Corporate Governance, ICGN Statement, World Bank Framework for Implementation), highlight board competencies as one of the vital issues (Aguilera et al., 2006; C. Ingley \& Van Der Walt, 2005; Pass, 2004). The general consensus within these guidelines aims to enhance board accountability towards shareholders whilst 
improving the effectiveness of the board. The emergence of voluntary codes of conduct has further highlighted CSRagenda (e.g. standards included in the Global Reporting Initiative and the UN Global Impact).

Typically, board independence is at the core of the agenda in these governance recommendations but the role of increasing NEDs competencies and roles as well more effective response to various stakeholder groups is also pointed out in some cases. Board competencies and roles have also attracted a significant amount of attention from the academic community. This stream of research has mainly focused on the effects of board competencies and roles on corporate performance. However, the relationship between specific board attributes and CSR practices remains relatively under-researched. This study uses two case study organisations and interviews 23 participants to uncover the vital NEDs competencies and roles for the integration of CSR into governance structure.

Hence, the aim of this paper is to enhance the current understanding of the effectiveness of non-executive directors in safeguarding stakeholders' interests. A combination of secondary and primary research methods is used to address this aim and contribute to the existing body of literature on the topic. Existing body of research on the studied phenomenon is reviewed and the outcomes of the review are enriched by the analysis of governance structures in two case study organisations operating in Saudi Arabia.

The findings uncovered in this study reveal that (i) independence of non-executive directors represents a common governance practice and that (ii) NEDs' competencies and roles represent a governance issue that should be addressed in CGcode to protect various stakeholder groups. The paper is structured into five chapters. The second chapter summarises the existing body of literature on the topic of non-executive directors' characteristics and examples of good governance codes are introduced. The third chapter outlines the research method including sampling, data collection and data analysis processes. In the fourth chapter, key outcomes of the research are presented. The final chapter critically examines the practical and theoretical implications of this study.

\section{Theoretical Background}

\subsection{Board Roles-Non-Executive Directors}

The general consensus in the academic debate highlights the importance of increasing the proportion of independent directors on the board. This recommendation is underpinned by an agency theory perspective which considers monitoring of the managers' actions on behalf of the shareholders to represent the key function of the board of directors (Eisenhardt \& Schoonhoven, 1996; Fama \& Jensen, 1983; Pass, 2004). Insiders (current or former managers and employees of the firm) or dependent outside directors (with business relationships with the firm) are found to be less effective in monitoring due to their inherent dependent on the organisation. Conversely, the motivation of NEDs is not compromised by dependency on the CEO or the firm itself. While the proponents of the board's independence have provided some empirical evidence to support this hypothesis by demonstrating the relationship between board's independence on firm performance, contradictory findings can also be found in existing body of research on the topic.

An opposing view has been presented by Baysinger and Hoskisson (1990) who associated the presence of inside directors on the board with better use of information and the resulting effectiveness gains. The proponents of this view rely on the use of resource dependence theory which perceives an organisation to be an open system, dependent on "external organisations and environmental" forces (Salancik \& Pfeffer, 1978; Alshareef \& Sandhu, 2014). In line with the resource dependence theory, boards can be perceived as providers of the following resources: advice and counsel, legitimacy, channels for communication of information with external organisations and preferential access for important elements outside of the firm (Hillman \& Dalziel, 2003; Salancik \& Pfeffer, 1978). The improvements in firm performance stem from the alignment of the firm with its external environment and the use of resources in overcoming external dependency, diminishing environmental uncertainty and lowering transaction costs (Salancik \& Pfeffer, 1978). Although both inside and outside providers can provide valuable linkages and resources to the board, this stream of research suggests that inside directors will exhibit higher motivation to provide such resources(Hillman \& Dalziel, 2003).

The functions of the boards of directors include participation in strategic decision-making, providing support to top management in defining the strategic context of the organisation and providing external legitimacy and networking(Demb \& Neubauer, 1992; Huse, 2005; Roberts, McNulty, \& Stiles, 2005). The contribution of non-executive directors to board control varies substantially in its effectiveness (C. Ingley \& Van Der Walt, 2005; Roberts et al., 2005; Zattoni \& Cuomo, 2010; Alshareef \& Sandhu, 2014). The antecedents of their effectiveness are (i) the extent of independence (Fama \& Jensen, 1983; Pass, 2004; Roberts et al., 2005)and (ii) the level of knowledge and skills (C. B. Carter \& Lorsch, 2013). The following section builds on this discussion, examines 
NEDs competencies and thus clarifies the required level of competencies in protecting stakeholder's interests.

\subsection{Competencies: Diverse Perspectives}

The broad interpretations of the term "competence" depicted in the existing body of research are found to hinder the development of a coherent conceptual framework. The most common interpretation is based on the notion that intellectual capabilities are required for the development of knowledge, and since operationalising of knowledge is essential for the development of skills, both are prerequisites for the development of competence alongside with further social and attitudinal aspects.

Arguably, competencies are context-dependent (Forbes \& Milliken, 1999; Zattoni \& Cuomo, 2010). The term can be defined as a specification of knowledge and skills and the application of these two construct in the context of the workplace and standards of performance required. In essence, competencies refer to the universal qualities which allow individuals to perform specific tasks regardless of national or organisational cultures or ethical background and functional area of job description (Zattoni \& Cuomo, 2010). Three particular types of competencies can be distinguished: cognitive (e.g. knowledge and skills), affective (e.g. attitudes and values), behavioural and motivational, all of which reflect the personal dispositions enabled an individual to perform well in a specific situation (Forbes \& Milliken, 1999; C. Ingley \& Van Der Walt, 2005). The utilisation of competencies leads to effective performance based on the individual's characteristics (Boyatzis, 1982). Competencies reflect the behavioural dimensions underlying the competent performance (Moore, Cheng, \& Dainty, 2002; Woodruffe, 1991). Moore et al. (2002) went even further and suggested that competencies link work, people and strategy and result in the performance improvements.

\subsection{Non-Executive Director's Competencies}

Members of the board of directors represent a "large, elite, and episodic decision-making group that faces complex tasks pertaining to strategic-issue processing" (Forbes \& Milliken, 1999). Given the complex nature of both executive and non-executive directors' jobs intertwined with difficulties. Zattoni and Cuomo (2010) argued that the problem of honest incompetence is even more substantial than the problem of self-seeking behaviour. Board effectiveness can be enhanced via a diverse competence base of board members(Roberts et al., 2005) and thus address the problem of honest incompetence. Knowledge and skills of directors can be categorised into functional and firm-specific aspects, both of which are essential for effective directors (C. B. Carter \& Lorsch, 2013; C. Ingley \& Van Der Walt, 2005). On one hand, the functional knowledge and skills go beyond the traditional aspect of management (e.g. finance, marketing and accounting) and include further aspects essential for the management of the relationship with a company's environment (Forbes \& Milliken, 1999). The general perception of non-executive directors excelling in public companies suggests that they are highly responsible and outperform other directors (C. Ingley \& Van Der Walt, 2005; C. B. Ingley \& Van der Walt, 2001). On the other hand, firm-specific knowledge and skills are vital for an effective director given the need to understand the company and its operations. Board discussion activity is based on the analysis of information provided by the management and directors' proactive approach in searching for further information related to the problem raised (Charan, 1998). A recent survey conducted by (C. B. Carter \& Lorsch, 2013) challenged the quality of firm-specific knowledge amongst non-executive directors. Whilst the participating CEOs confirmed the role of gaining a clear understanding of the firm's strategy for board members, the respondents also pointed out the fact that non-executive directors fail to grasp this knowledge. Overall, both functional and firm-specific knowledge are vital determinants of non-executive directors' effectiveness.

\subsection{Non-Executive Directors and CSR}

In line with the overall aim of this paper to explore the roles of NEDs in enhancing the level of CSR integration within the governance structure, this section reviews the existing body of research on the relationship between CSR and NEDs. The empirical body of research in this domain is very limited. An exception can be found in the study conducted by O'Neill, Saunders, and McCarthy (1989) who reported that outside directors put more emphasis on ethical concerns in comparison with their executive counterparts. Similar findings have been put forward by Ibrahim and Angelidis (1995) indicating that non-executive directors are less concerned with financial matters and focus on philanthropic initiatives more than inside directors. In a comparative study of socially responsible and non-socially responsible organisations, Webb (2004) uncovered that the socially responsible organisation had a higher proportion of non-executive directors in their boards. As a result, the existing body of research provides some evidence to support the outsiders' role in achieving social responsibility.

Based on the examination of non-executive directors' roles in the context of the service industry, Ibrahim and Angelidis (2011) associated the presence of non-executive directors with a higher inclination towards CSR. Contradictory findings have been reported by Coffey and Wang (1998) who found no significant impact of the 
number of non-executive directors in the board on the philanthropic activities of an organisation. The reliability of the conclusions drawn in these studies is however limited by the positivist methodology adopted and the fact that only few subjects responded to the questionnaires (Coffey \& Wang, 1998; Ibrahim \& Angelidis, 1995, 2011; O'Neill et al., 1989). The finding put forward by Ibrahim, Howard, and Angelidis (2003) that diverse boards encourage organisations' involvement in social activities can be explained with reference to the work of Johnson and Greening (1999)The authors associated non-executive directors with broader organisational goals in comparison to their executive counterparts. Although the legal responsibilities are the same for both categories of directors, the actual perceptions of these responsibilities seem to differ between outsider and insider directors.

Overall, the topic of the non-executive directors' role and its impact on corporate behaviour is found to be under-researched(Forbes \& Milliken, 1999; McNulty \& Pettigrew, 1999; Roberts et al., 2005). Practical difficulties, such as gaining access to high profile personalities due to their busy schedules, inhibit the research in this area (McNulty \& Pettigrew, 1999). Additional challenges impeding the research progress can be found in the lack of a general consensus on how to measure the impact of NEDs in adopting CSR in an organisation. Annual reports and other secondary sources of information are often used which neglects the perceptions toward social and environmental aspects. NEDs' perceptions stem from their competences and attitudes highlighting stakeholder's issues and the aim of meeting their expectations. The following section explores NEDs competence that drives the enhancement of directors' roles with reference to the two case study organisation during their implementation of CSR into their respective governance structures.

\section{Research Methodology}

This study uses a case study research method for the examination of the studied phenomenon. This qualitative research method is found to be more suitable for the development of a board competency framework due to the level of insight provided (Yin, 2013). Two Saudi corporations extensively involved in CSR have been selected as case study organisations. Case study data collection used a multiple sources of information such as archival records, open-ended interviews, direct observation, participant-observation. The using different sources of evidence butter understanding of existing problem (Creswell, 2013; Yin, 2013). Therefore, In-depth interviews with board members and executive managers have been conducted to gather primary data. Additional information was obtained from various company's documents and reports. The existing information on current CG structure and practices are investigated in order to explain what and how the NEDs' competencies enhance their roles in adopting the CSR practices within the organization. A triangulation process was developed in order to process information from numerous sources and thus provide a more complete picture of the studied phenomenon (Creswell, 2013). There are two companies have been agreed to be involved into this research investigation. The first company is one of petrochemical companies listed in Saudi stock exchange. This company has coded as Case study (A) in this research. While, the second case study is a company listed agricultural and food sector in Saudi stock exchange.

To gain a better understanding of how the NEDs' competencies enhance their roles in adopting the CSR practices within the organization, it was deemed useful to seek viewpoints derived from board members and executive managers involved different hierarchical levels of CG structure. Table 1 shows participants' positions educational qualifications, experience although demographic data was collected in brief as managers spoke mostly in the capacity of representatives of their respective organizations. In the study they are referred to participant codes, for example, the code of participants in case studies (A) (PCI 1, 2 and 3), while participants in case study (B) (AFI 1, 2 and 3).

This is due to participant confidentiality and their identity not disclosed in the study. In terms of the interviews, each lasted two hours in average and while they were conducted in Saudi to suit the needs of the respondents, interviews were recorded and transcribed from Arabia to English. Within each case study organisation, two interviews were conducted. The interview process started with establishing a relationship with interviewees and asking questions about overall perceptions of the three topics highlighted in table 2. These three topics with relevant questions were designed to acquire specific details relating to objective of this paper. 
Table 1. Profile of participants interviewed

\begin{tabular}{lllll}
\hline Participant Code & Demographic Data & & & \\
\cline { 2 - 5 } & Position & Experience (years) & Educational level & Functional Background \\
\hline Case study of Petrochemical company & & Bac & \\
\hline PCI 1 & Management level & 13 & MA & Chemical Engineering \\
PCI 2 & Management level & 16 & PhD & Chemical Engineering \\
PCI 3 & Board level & 25 & MA & Accounting and Finance \\
PCI 5 & Board level & 25 & MA & Law \\
PCI 6 & Management level & 20 & & Accounting and Finance \\
\hline Case study of Food and Agricultural company & & MA & Management \\
\hline FAI 2 & Board level & 15 & PhD & Management \\
FAI 3 & Management level & 20 & Bac & Engineering \\
FAI 4 & Management level & 20 & Bac & Accounting \& Risk management \\
\hline FAI 5 & Board level & 15 &
\end{tabular}

The interviews 'discussions were based on open- ended (Creswell, 2013). At the beginning, the researcher provided topics and main idea of the research (see table two), and the participants were probed of their opinion about these topics. A rational method was conducted to verify the responses with information from other sources (Yin, 2013). The participants were motivated to offer their own understanding into the problematic issues and this was later joined with responses from other participants and sources pointing to the fact. Given the potential negative effects on the scope of the study and the importance of data gathered, the researcher went beyond the use of a specific sequence of the guiding questions. Next section explores required NEDs competence that lead to improving the NEDs roles, by analysing the two case studies during their integration of CSR into governance structure.

Table 2. Topics addressed in interviews

\begin{tabular}{|c|c|c|}
\hline Corporate governance (CG) & Corporate Social Responsibility (CSR) & Board of directors (BOD) \\
\hline - Concept Structure, committees & - CSR Conception & - Board of directors (BOD) \\
\hline - Governance Codes of conduct codes & - CSR practices & - BOD Composition \\
\hline - Motives for good CG practice & - Strategic CSR, values, mission & - BOD Roles and Responsibilities \\
\hline - CG requirement disclosure & $\begin{array}{l}\text { - Most important stakeholders } \\
\text { - Measurement of CSR }\end{array}$ & $\begin{array}{l}\text { - Board size } \\
\text { - Board independences }\end{array}$ \\
\hline
\end{tabular}

\section{Research Findings}

\subsection{Case Study A}

This case study concerns a petrochemical company listed on the Saudi stock exchange. The company has radically changed its business strategy by integrating CSR into its operational activities. This change led to the establishment of a separate CSR governance structure in 2009.

\subsubsection{CSR Governance Structure}

In early 2009, the company drastically altered its operational activities and management structure to become a more socially responsible business. This was achieved by establishing a separate internal CSR governance structure. This result in the foundation of new executives committees and departments specialized in overseeing 
company's CSR in accordance with its operational activities. The company founded this structure in order to have various managerial authorities among its NED, executive, senior managers and employees. Nine NEDs are at the top of CSR governance structure supervisory and strategy-related duties. Other executive directors sit on relevant committees and head up departments. There are 15 executive directors, 6 of which head the various operational sectors of SBUs, while the rest head the various company functions. According to the company's strategic objective was set in 2007, highlights the integration of CSR within the operational activities is main objective. Therefore, the majority of the committees within this structure include executive members from SBUs.

The adoption of CSR is buttressed by CG structures and procedures (Cadbury, 1992; Alshareef \& Sandhu, 2015). Ideally, a governance structure should be closely aligned with a company's CSR strategy and business model so that the board can deal with any challenges the company faces. However, there is no such thing as a universal ideal governance structure, because such structures are constrained by various issues including company laws and codes of conduct (Enriques \& Volpin, 2007). A particular CG structure that meets the needs of one company's CSR practices might be inappropriate for others. Indeed, companies have widely varying governance structures due to different business models and stakeholder concerns. Nevertheless, adoption of the CG concept is essential if a company wants to become more socially and environmentally responsible.

One of participants (PCI 3) stated that building a CG structure which takes into account the interests of stakeholders would lead to ongoing business security:

Sound and effective CG is essential to our success. It ensures that the interests of all our stakeholders, including customers, employees, shareholders and the communities in which we operate, are safeguarded and promoted over the long term.

Participant (PCI 1) highlighted the importance of maintaining corporate control by improving the governance processes that encourage best corporate practices with regards to the environment, health, and employee security, as well as mitigating legal risks;

Our Corporate Control maintains and works to steadily to improve our CG processes, by building our capabilities and encouraging best practice throughout the company: Environment, Health, Safety and Security, Legal, Enterprise Risk Management, Internal Audit, and Business Process and Data Quality Governance.

Those participants confirmed that a CG structure is needed to meet the stakeholder expectations of thorough implementation of best practices in CSR. From the stakeholder perspective, CG is a safeguard for all company stakeholders, not only shareholders, which enable the company to maintain and control CSR practices. This represents a shift from a profit-centred model to a stakeholder centered-model.

\subsubsection{NEDs' Competencies}

As previously mentioned, the government own $70 \%$ of the company's equity while $30 \%$ is available to the public. Six of nine NEDs are appointed by the Saudi cabinet, and three are elected by the general shareholder assembly according to the company's CG policy.

\subsubsection{Ability to Understand the CSR Strategic Issues}

NEDs are at the top of the company's CSR governance structure, as all the issues reported from the CSR-related executive committees are compiled before these members. The lack of but are poorly represented within executive committees. In this context, participants were asked to assess NED competencies required to participate effectively in adopting best CSR practice. Participant (PCI 2) argued that NEDs need to understand strategic environmental and social obstacles that face the company. This company is following a strategy to integrate CSR into its operations in order to produce more environmentally friendly products. Unfortunately many of the company's NEDs do not understand strategic environmental and social obstacles, and as the following quote shows, nor do they have detailed understanding of the company's operational activity.

Ok, by generally looking at non-executive board members, they are considered less knowledgeable and experienced in the company's operational activity compared with executive members. This makes them unable to participate in decisions about strategic CSR-related issues which face the company as well as the strategic decisions and practical solutions to overcome obstacles.

While the company's CSR nature is integrated within the operational its activities, executives are more efficient to perform these tasks in due to they are more knowledgeable of specific issues of operational activities and participate in the daily operational activities of the company. Participant (PCI 7) confirmed the previous view that NEDs need to contribute more to the social strategy of the company:

I believe that non-executive members should be more active strategically in the company's socially responsible 
activities because the company needs innovative aptitude to create sustainable plans and serve the society and environment.

The lack of this aptitude limits the directors' strategic roles in developing social strategies for the company.

Ability to understanding of CSR governance issues.

In contrast to the limitations highlighted by previous participants, this executive also revealed that their NEDs understood governance CSR issues:

Throughout our meetings with them, I sensed that they possess strong motive to change the company's direction in its operational paradigms and social and environmental practices and wish the company to be more engaged with stakeholders 'expectations.

The NEDs' ability to recognise their company's stakeholders concerns and meet their expectations led to a change in business direction towards socially responsible practices. This was achieved by establishing a CSR governance structure which ensured development of CSR strategies and monitoring their implementation in SBUs.

\subsubsection{Ability to Represent Stakeholder Interests}

Participant (PCI 7) also confirmed the ability of NEDs members to present stakeholder's concerns within the boards' discussions:

There is a clear perception that NEDs are aware of the government's intention to move to a competitive economy that is based on sustainability for its success. I noted an important transformation in understanding matters of CSR and directing board discussions toward the concerns of stakeholders.

Sustainability and stakeholder issues are important areas of concern with respect to economic competitiveness in Saudi Arabia. The government's transition to a more competitive economy is administered by the Saudi Arabian General Investment Authority (SAGIA) (SAGIA, 2008). Therefore, BODs are considered as an essential resource to direct the company towards adopting best practices within the company. NEDs' ability to handle and present sustainability and stakeholder issues at board meetings enhances the company's effort to adopt CSR and improves its performance in line with stakeholders' expectations.

\subsubsection{Knowledge and Skills}

The participants identified three types of knowledge and skills as important competencies for BODs in order to assist them in CSR transition process:

- Specific knowledge of the company's operations;

- $\quad$ Skill in mitigating environmental and social risks;

- Skills in social accounting reporting.

Participant (PCI 6) asserted that having specialised knowledge of operational activities was crucial in developing a strategic planning process for CSR transition.

Disregarding experience and qualifications, the [board] member needs elevated knowledge in the industry. This allows the member to leverage his industry knowledge to participate in the strategic planning process within the transition to social and environmental responsibility.

I do not expect a [board] member to be specialised in the industry, but they should know about the operational activity of the company. For instance, our company operates in the petrochemicals sector, and hence, we need members with administrative background but also know the petrochemical aspects, its structure, and internal managerial details.

Participant (PCI 2) went on to discuss the importance of skill in mitigating environmental and social risks. This participant noted that this skill was possessed by executive directors who were responsible for the integration of CSR activities within the operational activities known as SBUs. This competency enriched the discussions within executive committees, and contributed to the successful integration of CSR into operational activities:

From my experience in executive management, I found the executives to have sufficient skill in identifying and mitigating environmental risks. This helped executive members within the CSR Council and steering committees to identify those risks caused by the operations and how to manage them...

However, not every director possesses such knowledge; Participant (PCI 3) also emphasised that directors should acquire skills in social accounting and reporting in order to monitor and review CSR activities. 
My background is accounting; when I was appointed as a non-executive director, I wasn't aware of social accounting and the analysis of company social and financial information. So, I developed [my skills] in this area, [familiarising myself with] different item terminology according to specific operations.

\subsection{Case Study (B)}

The group is one of the most successful multinational food groups in the Arabic Gulf and Middle East regions. It has a wide portfolio of businesses including foods, retail, and plastics. The group has a market capitalization of Saudi Riyal, 5,000,000,000 and is listed on the Saudi stock exchange. Its total workforce in Saudi Arabia and overseas is about 17,000 .

\subsubsection{Group's Corporate Governance Structure}

The company' BOD consists of elven NEDs and eight executive directors, including the Group's managing director. This complies with Article 12 of the CG regulation issued by Capital Market Authority. The Board is appointed by the general shareholders assembly for three years. The BOD's specializations are diverse includes administrative strategic planning, accounting, law, marketing, CG, HR, risk management, and mergers \& acquisitions (Board Report 2011). The Group's CG structure includes six governance committees, with the membership of which consists of Board Members; NEDs' specialists and executives. These committees have a special Charter, approved by the Group Board, to govern their scope of work and related procedures.

In 2004 the group developed a CG code to describe the practices and rules of corporate management, including disclosure principles, transparency, conflict of interest, confidential internal information, and stakeholders' interests, as well as the BOD's responsibilities, duties of the executive management including the managing director, and the boundaries of the group's levels of authority. Participant (FAI 2) noted that:

Our perception of CG is that it enhances corporate value by ensuring that the Group fulfills its commitment to shareholders, employees, communities, the environment and all other stakeholders through an effective and interactive CG framework.

The CG's conception may differ from one company to another, and usually depends on how the decision makers in the company view it. In this case, the adopted view of a CG conception focuses on stakeholder's model rather than profit model, which is mainly focus on the protection of the shareholders' interests. Therefore, the adoption of CG conception that protect all stakeholders' rights rather than the shareholders alone, this indicates that the basic requirements of CSR implementation are met within the group's governance structure. Participant (FAI 2) also commented that integration of CSR into governance structures enhanced the group's ability to conduct CSR practices:

There were managerial difficulties in monitoring, discussing and evaluating the performance of CSR activities. Let's say before 2004, the contributions of the group in CSR were limited to discrete charitable contributions to charities working in aged care and supporting orphans and widows who come to the group to get such financial aid, then our CSR ends on such point. Most of our board members were not satisfied with this; they argued that CSR activities must be sustainable. The integration of CSR into our CG structure made our CSR practice more precise, well organised and sustainable.

These comments revealed that before 2004 the group had not properly understood the concept of CSR. This misunderstanding made the CSR practices were limited to unorganized charity's collection, which does not enhance strategic concept of CSR activities that based on sustainability. Non-systematic CSR activities wasted money and effort. The group's shift to strategic CSR concept since 2004 led to CSR practices being formally integrated into overall CG structure, therefore, this lead to the organization of CSR activities through financial monitoring, discussion of CSR policies, strategic development; plans and goals, and evaluation of CSR performance by group's BODs.

\subsubsection{NEDs' Competencies}

NEDs constitute 57\% of the Group's board (11 of 19 members). NEDs are distributed over the committees within the Group's governance structure; their competences help them perform their governance roles.

\subsubsection{Ability to Represent Stakeholder Interests}

In this case study, the participants identified several NEDs' competencies as important to their roles in improving the group's social and environmental performance. A Participant (FAI 3) stated that NEDs' independence was valuable in representing the group's stakeholders:

NEDs have an independent view; this helps in determining our stakeholders' issues. Through my direct communication with NEDs in the CSR committee, I have no doubt that they are able to represent stakeholder's 
interests based on their social experience and knowledge.

The board's report in 2011 revealed that NEDs appointed to the CSR committee have specialised knowledge and expertise in CSR practices, helping them to identify and understand stakeholders' expectations and how to meet them.

\subsubsection{Ability to Provide Strategic Vision}

A participant (FAI 5) quoted above also commented that NEDs were considered as 'stakeholders' directors' who have ability to provide strategic perspective for CSR practices:

[We] always call them 'stakeholders' directors' and not NEDs ... this is because after the establishment of the CSR committee, NEDs gave us external views that helped us to identify stakeholders' needs. The NEDs outline the strategic vision that helps us in developing strategies for our CSR practices.

Therefore, the emerged NED's competencies above were derived as a result of

- Viewing the organization form the external environment;

- Communicating with stakeholder in close;

- Informed of the stakeholder needs.

\subsubsection{Ability in Providing Quality of Monitoring in CSR Board Committee}

A related criticism of the group's CG structure is that the CSR committee has an under-representation of NEDs. Nevertheless, A participant (FAI 4) noted that the NEDs appointed to the CSR committee were specialised in CSR activities and not taxed with other governance responsibilities. Their specialization of CSR committee, make them able to discuss and always ask questions in order to monitor CSR activities:

Yes, the CSR committee has fewer NEDs than executive members, but do not forget that NEDs are only specialized in CSR activities and they do not have other tasks, making them able to ask questions, follow up CSR activities.

\subsection{Case Studies Summary}

The two case studies of a petrochemical company (A) and food and agricultural group (B) were involved in the qualitative investigation in this purpose of this paper. A case study of a petrochemical company (A) revalued that board was aware of the negative environmental impact of the company's main activity; this awareness led the management to strategically priorities the integration of CSR into its operations in 2007. In order to achieve this objective, by the beginning of 2009, the company began radically altering its operational activities and management to become a more socially responsible business; this was achieved through establishing a new CSR governance structure, including:

- Founding new executive committees and departments specialised in overseeing the company's integration of CSR into its activities;

- Activating the board's role in integrating CSR into the six operational activities ;

- $\quad$ Providing sustainable CSR activities; and

- $\quad$ Providing more accountability to CSR practice at the board level.

However, a case of an agricultural and food group (B) was investigated with respect to the Board and management's views about the integration of CSR activities within the governance structure. The board perceived that the stakeholder governance concept was the foundation. The board was not satisfied by the group's formerly unsystematic CSR activities, and in 2004 adopted a strategic concept of CSR which made group contributions more organised and sustainable. This led to integration of CSR into governance by establishing a CSR committee. Management perceived that this committee activated the board members' in implementing and adopting CSR practice within the group.

Interviews with participants involved in both case studies revealed seven significant NED competencies that motivated board roles to integrate CSR into their governance structure. Table 3 summaries NEDs' competencies and their effects on adoption of CSR practices. 
Table 3. Findings of NED competencies and roles

\begin{tabular}{|c|c|c|c|}
\hline Competency & $\begin{array}{c}\text { Case Study } \\
\text { (A) }\end{array}$ & $\begin{array}{l}\text { Case Study } \\
\text { (B) }\end{array}$ & Potential Roles \\
\hline $\begin{array}{l}\text { Ability to understand CSR governance } \\
\text { issues }\end{array}$ & Supported & None & $\begin{array}{l}\text { - } \quad \text { Engagement with stakeholders' expectations } \\
\text { - } \quad \text { Control of socially responsible practices } \\
\text { - } \quad \text { Adequate planning for integration of CSR into } \\
\text { SBUs' operations } \\
\text { - } \quad \text { Executing CSR projects sustainably }\end{array}$ \\
\hline Ability to present stakeholders' concerns & Supported & Supported & $\begin{array}{ll}\text { - } & \text { Understanding CSR } \\
\text { - } & \text { Enhancing CSR performance } \\
\text { - } & \text { Meeting stakeholders' expectations } \\
\text { - } & \text { Directing discussion of the concerns of stakeholders } \\
\text { - } & \text { Independent view in determining stakeholders' } \\
\text { needs } \\
\text { - Comprehensive perspectives on our stakeholders' } \\
\text { needs }\end{array}$ \\
\hline Ability to provide strategic vision & None & Supported & $\begin{array}{ll}\text { - } & \text { Help management develop CSR strategies } \\
\text { - } & \text { Communicate closely with stakeholders } \\
\text { - } & \text { Informed about the external stakeholder needs } \\
\end{array}$ \\
\hline Ability to control CSR projects & None & Supported & $\begin{array}{ll}- & \text { Discuss, ask questions of CSR } \\
\text { - } & \text { Evaluate CSR activities } \\
\end{array}$ \\
\hline Specific knowledge of operations & Supported & None & $\begin{array}{l}\text { - Developing a strategic planning process for CSR } \\
\text { transition }\end{array}$ \\
\hline $\begin{array}{l}\text { Skill in mitigation of environmental and } \\
\text { social risks }\end{array}$ & Supported & None & $\begin{array}{l}\text { - Integrate CSR into operational activities } \\
\text { - Enrich the discussions and debates within } \\
\text { executives committee }\end{array}$ \\
\hline $\begin{array}{l}\text { Analytical skill of social accounting } \\
\text { reporting }\end{array}$ & Supported & None & $\begin{array}{l}\text { - Analysis of the company's social and financial } \\
\text { information } \\
\text { - Analysis of descriptive and quantitative data in CSR } \\
\text { reporting }\end{array}$ \\
\hline
\end{tabular}

\section{Discussion of Findings and Theoretical Propositions}

The investigation of non-executive directors' competences (NEDs) offered contradictory views and understanding over the impact of NEDs competence on their control and service roles as well as the strategies associated with CSR practices. However, the participants in the two case studies have emerged four NEDs' competences namely ability to understanding governance CSR issue; ability to present stakeholder's concerns; ability to provide strategic vision; ability to control of CSR projects within governance committee were importantly needed within board in order to perform their roles effectively in adopting the CSR practices. Of concern was the finding that majority of highlighted NEDs' competences were demonstrated by participants in case study (B). This can be referred to that board independence level in case study (B) was greater than case study (A), in the term of numbers of NEDs within governance committees, which assist the participants to provide precise view of which NED's competences were significantly effective in enhancing board roles in adopting CSR practices.

Therefore, the qualitative findings revealed that participants involved in two case studies, were agreed of perception that ability to present stakeholder's concerns was important NED's competence that lead to improving board roles by providing: independent view in determining company's stakeholder; comprehensive sight of company's stakeholders needs; understanding issues of CSR; Enhance CSR performance; meet stakeholders' expectation and directing discussion and debates toward the concerns of stakeholders. According to the stakeholder perspective the modern corporation is viewed as a responsible citizen in a democratic social system(C. Ingley \& Van Der Walt, 2005; Kiel \& Nicholson, 2003). As such, a business has an commitment to create a positive involvement into community and must therefore apply wide-ranging principles as foundation of decision-making (C. B. Carter \& Lorsch, 2013; C. B. Ingley \& Van der Walt, 2001; Kiel \& Nicholson, 2003). Based on this view, board of directors have a responsibility to consider all individuals or groups, who influenced 
by the business's decisions and actions and who can considerably influence the organisation's welfare in order to create an acceptable outcome to all stakeholders(C. Ingley \& Van Der Walt, 2005; Jamali, 2008; Kiel \& Nicholson, 2003). C. B. Ingley (2008) stated that effect of this competence on board of directors in according to this view is one of mediating and balancing competing stakeholder welfares in its roles.

Concerning ability to understanding governance CSR issue competence, the participants in case study (A) have pointed out that board with type of competence can generate potential benefits such as: engagement with stakeholders 'expectations: control over socially responsible practices; adequate planning for integration of CSR into SBU's operations and Sustainable implementation of CSR practices, which in turn to improving its roles in adopting the CSR practices. In addition, participants involved in case study (B) have been found to require types of competencies: ability to provide strategic vision and ability to control of CSR projects within governance committee. The ability to provide strategic vision competence has provided various benefits to group executive management by helping the management in developing CSR strategies; communicate with stakeholder in close and Informed of the external stakeholder needs while NED's ability to control of CSR projects was emphasised to improve the board monitoring role by: discuss, ask questions of CSR and follow up CSR activities.

These findings are in line with the resource based view of the firm which suggests that the board represent a valuable resource and that boards' competence can shape the sustainable competitive advantage of a firm. NEDs competences are perceived as "basic constitutive elements out of which board of directors transform inputs into outputs, or generate services" (Zattoni \& Cuomo, 2010). As a result, NEDs can enhance their roles by assembling, integrating and managing these resources (Ayuso \& Argandoña, 2009; C. B. Ingley, 2008; Russo \& Fouts, 1997).

\section{Conclusion}

The focus of this paper was put on exploration of NEDs' competencies that can enable organisations to move towards CSR and to examine the effect of these competencies on directors' roles. Two case studies were conducted and a total of 23 participants from board and management level took part in the study.

The topic of non-executive directors' competencies has attracted a significant amount of attention from the academic community. The general consensus in the existing body of research questions the quality of non-executive directors' competencies and their impact on active behaviour(C. B. Carter \& Lorsch, 2013; D. A. Carter, D'Souza, Simkins, \& Simpson, 2010; Roberts et al., 2005). In general, codes insufficiently cover the promotion of electing non-executive directors with significant competencies and experiences. Similar conclusions can be drawn in the context of an audit committee where the financial literacy is not an essential prerequisite for election yet. The situation is even more severe in the context of CSR as CG codes fail to consider NEDs' competencies and roles. As a result, the findings of this study are expected to contribute to the current level of understanding of competencies and roles of non-executive directors and result in improvement of CG codes in the context of stakeholder engagement. The code recommendations are strongly influenced by agency theory and as such, stakeholders' interests are largely neglected in the code regulations. Following a multiple-theoretical framework based on resource dependence theory, stakeholder theory and resource based view of the firm, the study highlighted the crucial relationship between NEDs competencies and their roles in the context of CSR.

The limitations of this study need to be acknowledged. The first limitation can be found in the focus on non-executive directors and other governance mechanisms contributing to the development of effective balances within a firm (Aguilera et al., 2006; Ibrahim \& Angelidis, 2011; Pass, 2004). Aguilera and Jackson (2003) have been largely neglected. Additional limitation can be found in the interconnected nature of the performance, board independence, ownership structure and top management characteristics and compensation (Agrawal \& Chadha, 2005; Aguilera et al., 2006). In essence, the analysis of a single governance mechanism does not provide a full picture of the studied phenomenon. Further limitations of the study can be found in the small sample size (two case study organisations). The external reliability of the study may be therefore limited and the applicability of the conclusions drawn is expected to be higher in the context of developing countries. Final limitation stems from the reliance on the qualitative interpretive approach adopted and the use of self-reported measures which raise the possibility of a social desirability bias.

\section{References}

Agrawal, A., \& Chadha, S. (2005). Corporate governance and accounting scandals. Journal of Law and Economics, 48(2), 371-406. http://dx.doi.org/10.1086/430808

Aguilera, R. V., Williams, C. A., Conley, J. M., \& Rupp, D. E. (2006). Corporate Governance and Social 
Responsibility: A comparative analysis of the UK and the US. Corporate Governance: An International Review, 14(3), 147-158. http://dx.doi.org/10.1111/j.1467-8683.2006.00495.x

Alshareef, M. N. Z., \& Sandhu, K. (2014). Evaluating Board Roles Performance in Adopting Corporate Social Responsibility (CSR) Practices. Journal of Modern Accounting and Auditing, 10(10).

Alshareef, M. N. Z., \& Sandhu, K. (2015). Integration of corporate social responsibility (CSR) into Corporate Governance: New model, Structure and Practice: A case study of saudi company. European Journal of Accounting Auditing and Finance Research, 3(5), 1-19.

Ayuso, S., \& Argandoña, A. (2009). Responsible corporate Governance: Towards a Stakeholder board of directors? http://dx.doi.org/10.2139/ssrn.1349090

Baysinger, B., \& Hoskisson, R. E. (1990). The composition of boards of directors and strategic control: Effects on corporate strategy. Academy of Management Review, 15(1), 72-87. http://dx.doi.org/10.2307/258106

Cadbury, A. (1992). Cadbury report: The financial aspects of corporate governance. London: Tech reprt, HMG.

Carroll, A. B. (2000). Ethical challenges for business in the new millennium: Corporate social responsibility and models of management morality. Business Ethics Quarterly, 33-42. http://dx.doi.org/10.2307/3857692

Carter, C. B., \& Lorsch, J. (2013). Back to the drawing board: Designing corporate boards for a complex world. Harvard Business Press.

Carter, D. A., D'Souza, F., Simkins, B. J., \& Simpson, W. G. (2010). The gender and ethnic diversity of US boards and board committees and firm financial performance. Corporate Governance: An International Review, 18(5), 396-414. http://dx.doi.org/10.1111/j.1467-8683.2010.00809.x

Coffey, B. S., \& Wang, J. (1998). Board diversity and managerial control as predictors of corporate social performance. Journal of Business Ethics, 17(14), 1595-1603. http://dx.doi.org/10.1023/A:1005748230228

Creswell, J. W. (2013). Research design: Qualitative, quantitative, and mixed methods approaches. Sage publications.

Demb, A., \& Neubauer, F. F. (1992). The corporate board: Confronting the paradoxes. Long Range Planning, 25(3), 9-20. http://dx.doi.org/10.1016/0024-6301(92)90364-8

Eisenhardt, K. M., \& Schoonhoven, C. B. (1996). Resource-based view of strategic alliance formation: Strategic and social effects in entrepreneurial firms. Organization Science, 7(2), 136-150. http://dx.doi.org/10.1287/orsc.7.2.136

Enriques, L., \& Volpin, P. (2007). Corporate governance reforms in continental Europe. The Journal of Economic Perspectives, 21(1), 117-140. http://dx.doi.org/10.1257/jep.21.1.117

Fama, E. F., \& Jensen, M. C. (1983). Separation of ownership and control. Journal of Law and Economics, 301-325. http://dx.doi.org/10.1086/467037

Forbes, D. P., \& Milliken, F. J. (1999). Cognition and corporate governance: Understanding boards of directors as strategic decision-making groups. Academy of Management Review, 24(3), 489-505. http://dx.doi.org/10.2307/259138

Hazlett, S. A., McAdam, R., Sohal, A., Shahin, A., \& Zairi, M. (2007). Corporate governance as a critical element for driving excellence in corporate social responsibility. International Journal of Quality \& Reliability Management, 24(7), 753-770. http://dx.doi.org/10.1108/02656710710774719

Hermalin, B. E., \& Weisbach, M. S. (2001). Boards of directors as an endogenously determined institution: A survey of the economic literature: National Bureau of Economic Research. http://dx.doi.org/10.3386/w8161

Hillman, A. J., \& Dalziel, T. (2003). Boards of directors and firm performance: Integrating agency and resource dependence perspectives. Academy of Management Review, 28(3), 383-396. http://dx.doi.org/10.2307/30040728

Huse, M. (2005). Accountability and creating accountability: A framework for exploring behavioural perspectives of corporate governance. British Journal of Management, 16(s1), S65-S79. http://dx.doi.org/10.1111/j.1467-8551.2005.00448.x

Ibrahim, N. A., \& Angelidis, J. P. (1995). The corporate social responsiveness orientation of board members: Are there differences between inside and outside directors? Journal of Business Ethics, 14(5), 405-410. http://dx.doi.org/10.1007/BF00872102 
Ibrahim, N. A., \& Angelidis, J. P. (2011). Effect of board members' gender on corporate social responsiveness orientation. Journal of Applied Business Research (JABR), 10(1), 35-40.

Ibrahim, N. A., Howard, D. P., \& Angelidis, J. P. (2003). Board members in the service industry: An empirical examination of the relationship between corporate social responsibility orientation and directorial type. Journal of Business Ethics, 47(4), 393-401. http://dx.doi.org/10.1023/A:1027334524775

Ingley, C. B. (2008). Company growth and board attitudes to corporate social responsibility. International Journal of Business Governance and Ethics, 4(1), 17-39. http://dx.doi.org/10.1007/s10551-007-9572-4

Ingley, C. B., \& Van der Walt, N. T. (2001). The strategic board: The changing role of directors in developing and maintaining corporate capability. Corporate Governance: An International Review, 9(3), 174-185. http://dx.doi.org/10.1111/1467-8683.00245

Ingley, C., \& Van Der Walt, N. (2005). Do board processes influence director and board performance? Statutory and performance implications. Corporate Governance: An International Review, 13(5), 632-653. http://dx.doi.org/10.1111/j.1467-8683.2005.00456.x

Jamali, D. (2008). A stakeholder approach to corporate social responsibility: A fresh perspective into theory and practice. Journal of Business Ethics, 82(1), 213-231. http://dx.doi.org/10.1007/s10551-007-9572-4

Johnson, R. A., \& Greening, D. W. (1999). The effects of corporate governance and institutional ownership types on corporate social performance. Academy of Management Journal, 42(5), 564-576. http://dx.doi.org/10.2307/256977

Kiel, G. C., \& Nicholson, G. J. (2003). Board composition and corporate performance: How the Australian experience informs contrasting theories of corporate governance. Corporate Governance: An International Review, 11(3), 189-205. http://dx.doi.org/10.1111/1467-8683.00318

McNulty, T., \& Pettigrew, A. (1999). Strategists on the board. Organization Studies, 20(1), 47-74. http://dx.doi.org/10.1177/0170840699201003

McNulty, T., Florackis, C., \& Ormrod, P. (2013). Boards of directors and financial risk during the credit crisis. Corporate Governance: An International Review, 21(1), 58-78. http://dx.doi.org/10.1111/corg.12007

Moore, D. R., Cheng, M. I., \& Dainty, A. R. (2002). Competence, competency and competencies: Performance assessment in organisations. Work Study, 51(6), 314-319. http://dx.doi.org/10.1108/00438020210441876

Nicholson, G. J., \& Kiel, G. C. (2004). A framework for diagnosing board effectiveness. Corporate Governance: An International Review, 12(4), 442-460. http://dx.doi.org/10.1111/j.1467-8683.2004.00386.x

O’Neill, H. M., Saunders, C., \& McCarthy, A. (1989). Board Members Background Characteristics and Their Level of Corporate Social Responsiveness Orientation: A Multivariate Investigation. Paper presented at the Academy of Management Proceedings. http://dx.doi.org/10.5465/AMBPP.1989.4977895

Pass, C. (2004). Corporate governance and the role of non-executive directors in large UK companies: An empirical study. Corporate Governance: The International Journal of Business in Society, 4(2), 52-63. http://dx.doi.org/10.1108/14720700410534976

Roberts, J., McNulty, T., \& Stiles, P. (2005). Beyond agency conceptions of the work of the non-executive director: Creating accountability in the boardroom. British Journal of Management, 16(s1), S5-S26. http://dx.doi.org/10.1111/j.1467-8551.2005.00444.x

Russo, M. V., \& Fouts, P. A. (1997). A resource-based perspective on corporate environmental performance and profitability. Academy of Management journal, 40(3), 534-559. http://dx.doi.org/10.2307/257052

SAGIA. (2008). The Saudi Responsible Competitiveness Index.

Salancik, G. R., \& Pfeffer, J. (1978). A social information processing approach to job attitudes and task design. Administrative Science Quarterly, 224-253. http://dx.doi.org/10.2307/2392563

Sarbanes, P. (2002). Sarbanes-oxley act of 2002. Paper presented at the the Public Company Accounting Reform and Investor Protection Act. Washington DC: US Congress.

Webb, E. (2004). An examination of socially responsible firms' board structure. Journal of Management and Governance, 8(3), 255-277. http://dx.doi.org/10.1007/s10997-004-1107-0

Willard, B. (2012). The new sustainability advantage: Seven business case benefits of a triple bottom line. New Society Publishers. 
Woodruffe, C. (1991). Competent by any other name. Personnel Management, 23(9), 30-33.

Yin, R. K. (2013). Case study research: Design and methods. Sage publications.

Zattoni, A., \& Cuomo, F. (2010). How Independent, Competent and Incentivized Should Non-executive Directors Be? An Empirical Investigation of Good Governance Codes. British Journal of Management, 21(1), 63-79. http://dx.doi.org/10.1111/j.1467-8551.2009.00669.x

\section{Copyrights}

Copyright for this article is retained by the author(s), with first publication rights granted to the journal.

This is an open-access article distributed under the terms and conditions of the Creative Commons Attribution license (http://creativecommons.org/licenses/by/3.0/). 